Parvez Ahmed Pirzado, 2019

Volume 4 Issue 3, pp. 1741-1760

Date of Publication: 26 th March, 2019

DOI- ttps://dx.doi.org/10.20319/pijss.2019.43.17411760

This paper can be cited as: Pirzado, P. A., (2019). Teaching Human Rights in Pakistani Schools: What are the Potential Barriers? PEOPLE: International Journal of Social Sciences, 4(3), 1741-1760.

This work is licensed under the Creative Commons Attribution-NonCommercial 4.0 International License. To view a copy of this license, visit http://creativecommons.org/licenses/by-nc/4.0/ or send a letter to Creative Commons, PO Box 1866, Mountain View, CA 94042, USA.

\title{
TEACHING HUMAN RIGHTS IN PAKISTANI SCHOOLS: WHAT ARE THE POTENTIAL BARRIERS?
}

\author{
Parvez Ahmed Pirzado \\ University of Technology Sydney (UTS), Australia
}

parvezpirzado@gmail.com

\begin{abstract}
Education plays an important role in development of any country. Education is considered one of the major contributors for developing success at local, national and global levels. Human Rights Education (HRE) promotes awareness about human rights and a way of information sharing among students, parents and the community at large, to develop skills in people to understand and combat violations of human rights. If children receive a high quality education, embedded with Human Rights concepts and principles, they can become responsible citizens and promote the human rights. Pakistan ranks at the lowest end of human development in the world. In the Human Development Index 2017, Pakistan ranks at 147th position (out of 188 countries). Pakistan is signatory to a number of international human rights Conventions and thus has pledged to protect the rights of citizens. However, recent international and national reports portray the overall human rights situation in the country as inadequate. The teaching of Human Rights is not formally included in Pakistani curricula, and there is lack of research on the subject of Human Rights Education in Pakistan.

This paper attempts to explore the place of human rights within the existing policy documents and school curriculum in Pakistan and barriers in teaching human rights concepts in primary schools of Pakistan. The paper will focus on the situation of human rights education with reference to the
\end{abstract}


policy documents and existing curricula of Social Studies and Islamic Studies subjects and a review of textbooks. The study seeks to identify the opportunities and constraints related to teaching of human rights concepts in schools, and possibilities of teaching human rights concepts in Pakistani schools. The paper will provide recommendations for improved practices of teaching human rights in schools. The study will provide implications for policy makers and education practitioners and will set the ground for future research. The study will also suggest further research human rights education in Pakistan.

\section{Keywords}

Education in Pakistan, Human Rights Education, Schools in Pakistan

\section{Introduction and Background}

This paper presents a discussion on the place of human rights within the existing school curriculum and the circumstances of teaching human rights concepts through Social Studies and Islamic Studies subjects in primary classrooms of Pakistan. The paper examines human rights concepts in Pakistani policy documents and curricula of Social Studies and Islamic Studies subjects. It seeks to identify opportunities and constraints related to the teaching of human rights concepts in schools and to propose further possibilities for research on teaching of human rights concepts in Pakistani schools.

Despite the fact that Pakistan is signatory to many international human rights treaties and conventions such as Convention on the Rights of Child (CRC), Committee on the Elimination of Discrimination against Women (CEDAW), Covenant on Civil and Political Rights (CCPR), the situation of Human Rights in the country is considered poor (Ali, 2000). Major international reports such as Human Rights Watch (HRW), 2017, Amnesty International, 2017, and the Human Rights Commission of Pakistan (HRCP), 2017, portray the worsening situation of human rights in Pakistan. Pakistan also faces many social problems such as poverty, a poor democratic system, security concerns and gender disparities at all levels (Jahangir, 2000). The proposed research focuses on the situation of teaching human rights in selected schools in Sindh Province.

The National Education Policy of Pakistan states "the aims of education are to produce individuals committed to democratic and moral values, such as respect for others, freedom of expression, awareness of fundamental human rights, and openness to new ideas, having a sense of personal responsibility and participation in productive activities in society for the common good" 
(Government of Pakistan, 2009, p. 18). It is evident that at the policy level the importance of teaching human rights related concepts is acknowledged, however it is important to see the extent to which and ways in which the teaching of human rights related concepts is practised at the school level.

In general, the quality of education in Pakistan is not effective. Nisar (2010) indicates that the teaching methodology in almost all of the public schools and most of the private schools, which follow the government curriculum, is surprisingly uniform. All these schools idealize discipline, place strong emphasis on routine, ask students to follow orders, just focus to complete the assigned tasks in time and use physical punishment to maintain discipline. Similarly, Barber (2010, p. 2) affirms, "Pakistan is without a good education system. Indeed, if we are to speak plainly - as the times require - we must admit that the current education system is very poor indeed and the major reason behind this failure is the lack of political will by the governments".

It is important to inculcate respect for human rights among children at a very early stage, so that their skills can be enhanced for promoting human rights from childhood. This can result in recognition of the importance of human rights and willingness to play their role for the promotion of human rights in society. The literature suggests that there is no structured and formal teaching of human rights concepts in Pakistani schools (Iqbal, 2005). Srinivasan (2009, p. 14) quoting an interview with Baela Raza Jamil ${ }^{1}$, states that, "the peace and citizenship projects in Pakistan are still largely donor-funded and have not really been integrated into the education system, however the debate on peace education in Pakistan is alive and vibrant, at least amongst civil society". It confirms that there is scant evidence and research on Human Rights Education (HRE) in Pakistani schools, and that current HRE initiatives are mostly initiated by the Non-Government Organization (NGO) sector. Nevertheless, it is encouraging that there exists at least some vibrancy among the NGOs and civil society, which can become a model to build on for HRE.

\section{Purpose and Importance of Education}

Education plays an important role in the development of any country (Hanushek, 2013; Little, 1992). There is a famous saying 'the child is the father [parent] of tomorrow'. This suggests that the child should be prepared in a way that $\mathrm{s} / \mathrm{he}$ is able to understand the responsibilities as an

\footnotetext{
${ }^{1}$ A Senior Educationist in Pakistan and owner of an education Non-Government Organization (NGO).
} 
adult. Retallic and Datoo (2005) define the purpose of education as "to develop students as selfdirected and lifelong learners". Education is considered one of the major contributors for developing successful nations. Freire $(1970,1974)$ argued that to become a literate was more than just learning how to read and write, but also to gain consciousness. He further added that the role to "educate" in formal education is often passive on the part of the student; however, there should be a reciprocal dialogue between teacher and learner. For Freire, the good education is one which makes people creative, active and responsible citizens. Hence, it is important for the teacher to help children become creative, active and responsible, by, for example, discussing social issues to help understand the environment around them. Freire further stresses that creating awareness; breaking the silence and enabling people to participate in social change or transformation should be the goal of education. Similarly, Dewey (1916) advocated education where children receive learning opportunities that enable them to link and apply present content to previous experiences and knowledge. For Dewey, education enables children to live better, individually and collectively, as the child learns by doing. According to Dewey, democratic curriculum must present situations where problems are relevant to the situation of living together.

Little (1992) describes education as a form of investment within the concept of development, without which societies cannot progress. She further explains that "the new concept of development emphasizes the growth of people as well as income, the quality of life, the participation of people in their own development and human freedom, and education is seen to serve all three" (p. 6). Qureshi, Pirzado and Nasim (2007) consider teachers as role models, authority figures and change agents for their students in the classroom and they influence the learning process of students. Retallic and Datoo (2005) conclude that in order to transform traditional schools into effective schools a long journey and movement is required to progress towards a vision. They believe that if schools are transformed they are likely to have a significant effect on improving the quality of education for children and ultimately on changing the society and nation to which they belong.

The meaning of the term "quality education" often remains undefined (Chapman \& Adams, 2002). Various authors define quality in a variety of ways. The United Nations Educational, Scientific and Cultural Organization (UNESCO) asserts that

Two principles characterize most attempts to define quality in education: the first identifies learners' cognitive development as the major explicit objective of all education systems. Accordingly, the success with which systems achieve this is one indicator of their quality. 
The second emphasizes education's role in promoting values and attitudes of responsible citizenship and in nurturing creative and emotional development (2004, p. 29).

Primary school is the place where a child starts learning new concepts. Schunk (1990, p. 72) affirms that the school environment provides basic opportunities for children to explore, develop and evaluate their skills and attitudes, because "social comparisons compare one's performance with those of others". Siddiqui (2010) urges that schools should inculcate basic ethics such as truthfulness, punctuality, keeping a promise, caring and sharing, politeness, patience, tolerance, equality, love for peace and respect for others among students. He stresses that a good school works for the moral development of students through curriculum, pedagogy and life skills.

\section{Human Rights Education and its Implementation}

Human Rights Education (HRE) is an approach that promotes awareness about human rights and a way of information sharing among students, parents and the community at large, to develop skills in people to counter violations of human rights (Tibbitts, 1996). The stress on HRE can be traced back to at least the Universal Declaration of Human Rights (UDHR, 1948). The preamble of the UDHR states "The declaration shall strive by teaching and education to promote respect for these rights and freedoms and by progressive measures, national and international, to secure their universal and effective recognition and observance". The UDHR advocates the promotion of human rights through teaching and education to reduce violations of human rights and to build a peaceful and equitable society. Although, the importance of HRE is evident in the UDHR, but HRE attracted more attention in later years. In 1974, UNESCO moved to place HRE on the agenda of a General Conference, and ultimately all member states unanimously adopted the recommendation concerning education for international understanding, co-operation and peace and education relating to human rights and fundamental freedoms (Horn, 2009). On the occasion of the thirtieth anniversary of the declaration of the UDHR, the first international congress on the Teaching of Human Rights was organized in 1980. The purpose of the congress was to discuss ideas for the teaching of human rights. The resolution of the congress advocated call for special efforts to promote human rights, particularly by stressing the educational approach. The conference speakers recommended recognition for human rights education and proposed comprehensive models for human rights education in and beyond schools (UNESCO, 1980).

The Convention on the Rights of the Child (UNESCO, 1989) advocates types of education 
(HRE) for children, which can prepare them to contribute to their society and develop a spirit of peace, dignity, tolerance, freedom, equality and solidarity. Article 29 of the Convention on the Rights of the Child (CRC) states "Education shall be directed to the development of respect for human rights and fundamental freedoms, and for the principles enshrined in the charter of the United Nations (UN)" (UNESCO, 1989). The Vienna World Conference on Human Rights in 1993 specially focussed on the Human Rights Education. Paragraphs 78 and 81 of the Declaration describes HRE as an essential element for the promotion and achievement of stable and harmonious relations among communities and calls for specific programmes and strategies for ensuring the widest human rights education and dissemination of public information. The conference also declared 1995-2004 as the UN Decade for Human Rights Education (Human Rights Education Alliance (HREA), 2010). This period was an important phase for the advancement of HRE, as many countries initiated various projects related to HRE and the decision of decade for HRE encouraged countries to introduce HRE in and outside schools.

Education plays an important role in improving the human rights landscape. A quality education, which creates understanding and respect for human rights, can help children to develop as active and responsible citizens capable of contributing to society. A lack of awareness and understanding among citizens towards human rights principles can aid and abet human rights violations. Mihr and Scmitz (2007) define HRE at three levels; i) at a cognitive level, to provide basic knowledge and information about universal human rights standards; ii) at an emotional awareness level, to create a consciousness of human rights and their violations, and iii) at an active level, to provide individuals with the skills needed to effectively prevent and combat human rights violations. Horn $(2009$, p. 61) argues that "children have a right to education, but the education that they ought to receive is not ideologically neutral: it is compelled to include education on human rights”. Nussbaum (2010) believes that learning which brings creativity, innovation, critical thinking and citizenship concepts among children is essential.

Childhood is the age when qualities such as honesty, courage, discipline, cooperation and love are developed in children (Quddus 1990). Therefore, if HRE is introduced at an early stage (ideally at the primary level), respect for human rights can be developed in children and their skills can be enhanced so that they promote human rights, as HRE is a long-term strategy with sights set on the coming generations (Claude 2005). Tibbitts (1996) believes that human rights education can be part of the elementary grade curriculum because it is essentially about human dignity, freedom, 
and responsibility, which already exists in the curriculum. Therefore, it is desirable to introduce human rights education into schools at an early stage. Burridge and Chodkiewicz (2017) propose that teachers should move towards a more transformative learning experience where students learn about and for human rights and HRE needs to be based on a transformative educational practice that adopts a "whole of school" model, connected to its local and global communities.

There are three aspects of education embodying children's rights. These are i) the right to education, ii) rights within education, and iii) rights through education (Verhellen, 2003, p. 201). The first aspect ensures that every child has a right to a quality education, the second aspect urges for a caring environment and a context in which children's rights are protected while they receive education, and third aspect concerns teaching about human rights so that children become active and responsible citizens to exercise respect and promotion of human rights. Similarly, The United Nations Children's Fund (UNICEF, 2007) provides a conceptual framework, which highlights the need for a holistic approach to education, which should address following three elements:

The right of access to education (Education throughout all stages of childhood and beyond, availability and accessibility of education and Equality of opportunity).

The right to quality education (A broad, relevant and inclusive curriculum, Rights-based learning and assessment and Child-friendly, safe and healthy environments).

The right to respect in the learning environment (Respect for identity, Respect for participation rights and Respect for integrity).

According to Nasab and Meghdadi (2012, p. 275) "Human rights education in Muslim societies has not been effective and has not been able to meet the criteria of satisfaction because there have been some challenges in previous educational methods most of which arise from lack of appropriate educational leadership".

HRE is a broad term and relates to other, similar concepts such as Social Education, Civics Education, Peace Education, Citizenship Education, and Cultural Education. These concepts can assume different meanings and purposes, but are very closely related (Shuttleowrth, 2009). Civics Education covers some aspects of Human Rights and assists young people in learning their roles and duties to perform as active citizens (Heater, 2003). Similarly, Citizenship is a concept which falls under the broad theme of Human Rights. Citizenship education is the preparation of the individual to participate as active and responsible citizens in a society. 


\section{Country Profile: Pakistan}

Pakistan, being an economically fragile country, placed in 147th rank (out of 188 countries) of the Human Development Index (HDI) in the Human Development Report (HDR) of 2017 (UNDP, 2017). Pakistan has been stagnant at this rank for the last ten years, with slight variation of two ranks. Pakistan faces many challenges such as rising population, urban-rural divide, natural disasters, political conflict with the neighboring country India and increasing violent extremism. As per the 2017 population census, Pakistan's population is 208 million with a 2.4 per cent annual growth rate (Government of Pakistan, 2017). In Pakistan, 60.3 per cent population live on less than US \$2 a day (Human Development Report, 2016), the threshold of absolute poverty. The poor in Pakistan have suffered not only from low incomes but also from limited access to basic requirements such as education, health, clean drinking water and proper sanitation (Government of Pakistan, 2003: 11). One of the major reasons behind this is inadequate funding for the social sector, as a large proportion of the budget is devoted to the military expenditure to maintain the status as a nuclear country and to cope with the political tension with neighbouring India (World Bank, 2017).

Pakistan is signatory to several major international conventions and treaties. Pakistan has been a signatory of the Universal Declaration of Human Rights (UDHR) since 1948. In addition, Pakistan is signatory of the following treaties (OHCHR, 2017):

Table 1: List or Treaties and Conventions, Pakistan is Signatory to

\begin{tabular}{|c|c|}
\hline Treaty & Ratification Date \\
\hline $\begin{array}{l}\text { CERD - International Convention on the Elimination of All Forms of Racial } \\
\text { Discrimination }\end{array}$ & 21 Sep 1966 \\
\hline CRC - Convention on the Rights of the Child & 12 Nov 1990 \\
\hline $\begin{array}{l}\text { CEDAW - Convention on the Elimination of All Forms of Discrimination } \\
\text { against Women }\end{array}$ & 12 Mar 1996 \\
\hline CESCR - International Covenant on Economic, Social and Cultural Rights & 17 Apr 2008 \\
\hline $\begin{array}{l}\text { CAT - Convention against Torture and Other Cruel Inhuman or Degrading } \\
\text { Treatment or Punishment }\end{array}$ & 23 Jun 2010 \\
\hline CCPR - International Covenant on Civil and Political Rights & 23 Jun 2010 \\
\hline $\begin{array}{l}\text { CRC-OP-SC - Optional Protocol to the Convention on the Rights of the } \\
\text { Child on the sale of children child prostitution and child pornography }\end{array}$ & 05 Jul 2011 \\
\hline CRPD - Convention on the Rights of Persons with Disabilities & 05 Jul 2011 \\
\hline
\end{tabular}




\section{Treaty}

CRC-OP-AC - Optional Protocol to the Convention on the Rights of the Child on the involvement of children in armed conflict

Source: The Office of the United Nations High Commissioner for Human Rights (OHCHR) Website (OHCHR, 2017).

Pakistan, as a member of the United Nations, agrees to the human rights obligations under the UDHR. Ali (2000) states that some Muslim countries, including Pakistan, might see "Human rights" as a western agenda, but the Western tradition can be seen as a useful starting point for the location of human rights within Islam, as the Quran provides a way of life, which asserts itself as beneficial for all beings. Syed (2008) provides three alternative Islamic contexts i.e. 1) Islamic Orthodox, 2) Islamic Western, and 3) Islamic Modernist. He further provides examples of various countries including Pakistan, where an increasing number of women are participating in economic activities. The 1973 Constitution of Pakistan (Government of Pakistan, 2012) promises equal rights to all citizens, repudiates discrimination on the basis of gender alone, and affirms steps to ensure full participation of women in all spheres of life. Chapter 1 of the Constitution "Fundamental Rights" provides the list and description of 28 rights, such as right to education, equality of citizens, freedom of speech, freedom to profess religion, which are enshrined under the constitution.

The implementation of the rights outlined in the constitution has been a challenge; due to recurring military governments (Jahangir, 2000). Pakistan's former Prime Minister Benazir Bhutto believes that the Qur'an (Holy Book of Islam) preaches about peace, plurality and the democratic traditions of consensus (Bhutto, 2008). She argues that Islam supports various human rights, including the rights of women, but people (military leaders) have misinterpreted and have used Islam for their own benefits, especially during General Zia-ul-Haq's military rule (Bhutto, 2008). Ms. Bhutto's becoming a prime minister itself offered hope for Pakistan towards moderate secularism; however, her second term as prime minister was cut short. There is still a hope that Pakistan's human rights landscape and education situation will improve in coming years. Recently, Malala Yousafzai, who stood up for education and was shot by a militant group, has portrayed a positive image of Pakistan. In her book "I am Malala" (Yousafzai, 2013) she has portrayed the challenges towards girls education in Pakistan, however she is hopeful that majority of people in the country support liberal views and demand for the rights for all people in the country. After receiving the Nobel Prize by Malala, the importance of female education and equal rights of males and females 
have been highlighted.

\section{The Education System and the State of Education in Pakistan}

The state of education in Pakistan is unsatisfactory. Pakistan failed to meet the Education for All target for universal primary education by 2015 . The overall net enrolment rate in Pakistan at the primary level is 73.8 per cent, comprising 79 per cent boys and 68 per cent girls. The adult literacy rate $(15+$ years $)$ is also very low and reported at 57 per cent overall and just 44 per cent for females (UNESCO, 2017). There are 423,573,000 students enrolled in 2,428,000 schools in Pakistan with $70 \%$ of students at primary level (Government of Pakistan, 2017). Pakistan's median age is 22.7 years (Worldometers, 2018), which means there is high proportion of young people in Pakistan. Sindh, which is the second largest province of Pakistan with a population of 48 million, has $4,145,219$ students enrolled in 45,447 schools. The situation in rural areas is worse than in urban areas. The literacy rate in rural areas is 49 per cent compared to 74 per cent in urban areas (Government of Pakistan, 2017). Pakistan's progress in Education compared to other countries in South Asia is also poor. For example, Pakistan's literacy rate of 57\% is less than Bangladesh (62 per cent), Nepal (65 per cent), India (72 per cent) and Sri Lanka (93 per cent) (UNESCO, 2017).

There are four different education systems in Pakistan (Retallic \& Datoo, 2005); the state public education system operated by the state government; private schools run by the private for profit organizations (charging fees); madrassahs (religious schools) established by religious organizations, with funding from other Islamic-majority countries; and community based schools managed by Non-Government Organizations (NGOs), philanthropists or community organizations (p. 23). The state education system is the largest in the country. According to Government of Pakistan (2017), in total 63 per cent of all students are enrolled in the government public schools, 34 per cent in private institutions including NGOs or community organizations, and only 3 per cent in madrassahs (religious schools). The British in the Indian sub-continent (before Partition) introduced the state-run education system ${ }^{2}$. After partition in 1947, Pakistan continued to follow the same system for many years. During the Prime Minister Zulfikar Ali Bhutto's regime, in the early 1970s, the curriculum was revised to inculcate "socialist" values. During the General Zia-ul-Haq's military rule (1979-1985) the curriculum was revised to promote "Islamic ideology" (Nisar, 2010, p. 49-50).

\footnotetext{
${ }^{2}$ In 1947, the British India was divided in two independent countries, i.e. India and Pakistan.
} 
According to the constitution of Pakistan's Article 25-A, education is free and compulsory for all boys and girls up to the age of 16 years. After the recent Education Policy in 2009, Pakistan's existing formal education system is organised into the following stages.

The history of the education system in Pakistan shows that the system has always struggled to implement policies at the school level. Barber (2010), while presenting the chronology of education policies in Pakistan, summarises,

If one looks at the history of education reforms, it can be seen that none of them succeeded in past. The first five-year plan in 1956 set a target of universal primary enrolment in five years. It did not happen. In 1979 another target of 68 per cent enrolment by 1982 was set. It did not happen. In 1988 yet another target was set, this time for universal enrolment by 1992-93. Again, it did not happen. And, as we have seen, the target of universal primary education by 2015 still does not seem to have happened (p. 13).

Barber's forecast materialized; Pakistan missed the universal primary education goals by 2015 and the progress on other indicators, such as the literacy rate and number of out-of-school children, remains poor.

The traditional education system in Pakistan is more teacher oriented than student centered. My personal experience of working in the education sector in Pakistan for almost two decades suggests that in most of the government schools of Pakistan teachers rarely provide opportunities for talking, discussions, argument, sharing and social interaction in the classroom, and they only focus on completing the syllabus. According to Dean (2005), most teachers believe that their responsibility in the school is to provide instructions in academic subjects and prepare students to do well in exams. In such circumstances, children are more likely to become silent and passive, rather than active learners and thinkers.

Gender disparities in Pakistan's education system have been widely reported in the literature. There are fewer girls in schools compared to boys. Especially in rural areas, boys garner more attention from their parents and dominate classroom space at all educational levels. Qureshi, Pirzado and Nasim (2007) point out that communities in rural (and some semi-urban) areas of Sindh perceive value of education from three dimensions; its economic, socio-economic and socio-cultural aspects. They further clarify three aspects as (p. 133);

- The economic aspect anticipates good jobs for children;

- The socio-economic aspect invests more in boys' education as they are the providers for the family; 
- The socio-cultural aspect maintains the social norms such as not sending girls to co-education schools, especially as they grow older (beyond primary level) and the fear that girls will get more freedom if they are educated more.

According to the Government of Pakistan (2017), the overall education system accommodates 56 per cent male students as compared to 44 per cent female students. In Pakistan, many families view the formal education of girls as a waste of their resources and give priority to educating sons. There is a general belief that sons will be the ones to support the parents in their old age and that any economic gain that results from educating a girl will go to her future husband and his family (Qureshi, Pirzado and Nasim, 2007). Poor households sometimes see investing in girls' education as pointless, as they expect daughters to leave the household upon marriage (Oxaal, 1997). This reduces the parents' motivation in investing in their daughters' education. In Pakistan, the average family comprises five children (Population Council, 1998) and income-generating opportunities are limited for most of the population. In this situation, children of poor families also support their parents in income-generating activities. In cases of extreme poverty, children may contribute up to 40 per cent of family income (Department for International Development (DFID), 2001).

Despite challenges, there also have been some positive examples in Pakistan's education system. Few examples are summarised below;

Qureshi and Shamim (2009) by citing the work of researchers, conclude that in Pakistan's education system, there are more stories of failure than success, however they are optimistic that there is hope for improvement. They quote "Schooling and Schooling Practices in Pakistan" and note that all the studies presented therein report that individual teachers, despite their weak content knowledge and other constraints, are willing to learn and enthusiastic about implementing innovative ideas to improve learning conditions in schools and classrooms for enhanced student outcomes (Qureshi and Shamim, 2009).

Bashiruddin and Retallic (2008) present four stories of Pakistani teachers, who became successful teachers by attaining higher education. Rettalic and Farah (2005) summarise case study research among teachers who transformed their classrooms after receiving training. These teachers were neither highly qualified nor high achievers of top universities, but were just 'ordinary teachers'. The research shows that even teachers with average academic background can perform well and transform their schools if they are well trained. 
The Learning and Educational Achievements in Punjab Schools (LEAPS) Report (2007) concluded that private schools in low-income groups perform better than public schools in the same region. The reason for this seems to be the better learning opportunities and effective monitoring system in the private schools.

My personal experience as an education researcher suggests that teachers who receive training, try to bring a positive impact in their classrooms by initiating a culture of active learning where children were encouraged to participate. Similarly, I have seen schools with vibrant learning environments, where children are engaged in healthy discussion with their teachers and children are seen as active learners.

The proposed doctoral study will further add the knowledge about how Pakistani classrooms look like, specially related to human rights teaching.

\section{Previous Research on Human Rights Education in Schools in Pakistan and other Countries}

There have been various studies on Human Rights Education globally. Below is a brief review of the relevant studies on Human Rights Education.

A study by Bromley (2011) examined the content of required civic education textbooks in Canada to examine whether and how notions of national identity incorporate the principles of human rights and multiculturalism. This study found that traditional notions of national identity are reshaped in response to the rise of emphases on human rights and multiculturalism. Hence, Bromley concluded that a "human rights" concept is gaining importance in civic education textbooks.

A study by Seker and Topsakal (2011) explored the level of ability to adopt and apply organizational democracy by teachers and administrators in primary schools. 486 teachers and 71 administrators were randomly chosen as the sample. The study concluded that managers and teachers in primary schools have adopted organizational democracy but have reasonable view about practicability of organizational democracy.

Al-Edwan (2010) carried out a study and proposed a list of human rights principles that the Jordanian Elementary stage social education textbooks lack. The study also aimed at examining or exploring the extent to which human rights principles are present, sequenced and integrated in these textbooks. Results indicated that there was a disproportion of human rights principles in the social education textbooks of the Elementary stage, there was poor sequencing of human rights principles 
in these textbooks, and no statistically significant differences in the integration level of human rights principles into textbooks of social education between fifth, sixth and seventh grades. The findings of the study led to a suggestion for an inclusion of five components consisting of 28 human rights dimensions; i.e. civil rights, political rights, economic rights, social rights and cultural rights. Another study by Aslan and Karaman-Kepenekci (2008) found that Human Rights issues are more frequently included in Turkish textbooks than in French textbooks. Rights, Peace and Tolerance subcategories hold the first three places in textbooks of both countries.

The account of the few studies mentioned above provides some scope of research on various aspects of HRE in various countries of the world, including a Muslim-majority context. However, there is very limited research on the topic of Human Rights Education in Pakistani schools and curriculum. Iqbal (2005) provides a few smaller level initiatives related to human rights education in Pakistan, but concludes that although there are private sector initiatives on peace and human rights education programmes in Pakistan, there is no regular or long-term initiative by the public sector education system. Jahangir (2000) considers civil society as a potential stakeholder for building a consensus on the basic principles of human rights. She believes that civil society organizations can find a place for the promotion of human rights through education and to build pressure for the government to place the human rights on the political agenda. Srinivasan (2009) confirms that the Human Rights Education Programme (HREP) or the Children's Museum for Peace and Human Rights, as it is presently known, is one of the earliest known peace education programmes, established in 1995.

A study by Hina, Ajmal, Rahman and Jumani (2011, p. 42) concluded, "The textbooks of social studies at secondary level in Pakistan do not fully focus on citizenship education”. According to the study there is very little focus given to different components of citizenship education. The contents of the book did not depict national objectives such as imparting awareness about various aspects of socio-economic activities at national level and the role played by Pakistanis in the development of their society.

Another study by Faria and Dean (2011) on Pakistani schools found that children feel that it is important to learn about local and global social issues at the school, but there is no such provision in the existing curriculum to teach such topics to children. There are a few topics in the social studies curriculum such as Elections, but these only provide simple information to students. The study suggests that time should be devoted to discuss various social issues in classrooms and involve 
children in interactive work to build their enthusiasm and help them to realize their role as active citizens of the society.

\section{Conclusion}

The paper has discussed the situation of overall education in general and human rights education in Pakistan. The paper also presented human rights education programs and research on human rights education in other countries of the world. Based on the literature review following are the main barriers towards the teaching of human rights concepts in Pakistani classrooms.

- Lack of will among decision makers

- Unclear guidelines for implementation of Human Rights Education

- Shortage of professional development opportunities for teachers in the area of Human Rights Education

- Absence of supporting material on teaching HRE in classrooms

Although there has been implicit attention to Human Rights Education in Pakistan's policy documents and the national curriculum, there has been a dearth of evidence of teaching of human rights concepts in Pakistani classrooms.

There has been only meagre research into classroom practice in relation to teaching of human rights concepts in Pakistani classrooms. The author of this article is planning a large in-depth study on teachers' understanding and their practices of teaching human rights concepts in Pakistani schools. The purpose of the study is to analyse the situation of teaching human rights in Pakistani schools and identify the barriers in teaching human rights education in Pakistani schools. It is expected that the study will add new knowledge and provide implications for the teaching of human rights concepts in Pakistani schools.

\section{References}

Ahmed, Ishtiaq, (2011). The politics of religion in South and Southeast Asia. Routledge, Abingdon, Oxon; New York, NY.

Al-Edwan, Z., S. M. (2010). Human rights principles in the social education textbooks of the elementary stage in Jordan. European Journal of Social Sciences, 15(2), pp.183-291. 
Ali, Shaheen Sardar (2000). Gender and human rights in Islam and international law: equal before

Allah, unequal before man? The Hague: Boston: Kluwer Law International.

Amnesty International (2017). Annual Report 2016. Retrieved from

\section{https://www.amnesty.org/en/countries/asia-and-the-pacific/pakistan/report-pakistan/}

Aslan, C. \& Karaman-Kepenekci, Y. (2008). Human Rights Education: A Comparison of Mother

Tongue Textbooks in Turkey and France. Mediterranean Journal of Educational Studies, 13(1): 101-124.

Barber, Michael (2010). Education Reform in Pakistan: This Time It's Going to Be Different. Islamabad. Pakistan Education Taskforce.

Bashiruddin, A. and Retallick, J. (2008). Becoming a teacher in the developing world. Karachi, the Aga Khan University.

Bhutto, B. (2008). Reconciliation: Islam, democracy, and the West. New York: Harper.

Bromley P (2011). Multiculturalism and human rights in civic education: The case of British Columbia, Canada. Educational Research 53(2): 151-164.

Burridge, N., \& Chodkiewicz, A. (2017). Educating teachers about human rights: building a rights based culture in Australian schools. Asia-Pacific Journal of Teacher Education, 45(5), 455468.

Chapman, D., and Adams, D. (2002). The Quality of Education: Dimensions and Strategies. Hong Kong: Asian Development Bank Publication.

Claude, R. (2005). The Right to Education and Human Rights Education. SUR - International Journal of Human Rights, Vol. 45 (2), 39-65.

Dean B. (2005). Cooperative Learning in Classrooms. In Retallic J. and Farah I. (Eds) Transforming Schools in Pakistan; Karachi, OXFORD

Dewey, J. (1916). Democracy and Education. New York: Macmillan.

DFID (2001). The Challenge of Universal Primary Education. London: Department for International Development.

Faria, C. F. and Dean. B. L. (2011). Young Pakistani Citizen's Vision for Tomorrow. Journal of Research and Reflections in Education. June 2011, Vol.5, No.1, pp 53 -95.

Flowers, N. (Ed.) (1998). Human rights here and now: Celebrating the Universal Declaration of Human Rights. Minneapolis, MN: Amnesty International USA and University of Minnesota Human Rights Resource Center. 
Freire, P (1974). Education for Critical Consciousness. London: Sheed and Ward Ltd.

Freire, P (1970). Pedagogy of the Oppressed. New York: The Seabury Press.

Government of Pakistan. (2012). 1973 Constitution of Pakistan. Islamabad, Pakistan.

Government of Pakistan (2017). Pakistan Education Statistics 2015- 16. Islamabad, Government of Pakistan.

Government of Pakistan (2009). National Education Policy 2009. Islamabad: Ministry of Education, Pakistan.

Government of Pakistan (2003). Country Report on Decentralization in the Education System of

Pakistan: Policies and Strategies. Islamabad. Ministry of Education, Pakistan.

Hanushek, E. (2013). Economic growth in developing countries: The role of human capital.

Economics of Education Review, 37.

Hina, K., Ajmal,M., Rahman, F., and Jumani, N. (2011). State of Citizenship Education: A Case

Study from Pakistan. International Journal of Humanities and Social Science.

Horn, N. (2009). Human Rights Education in Africa. Bosl, A and Diescho, J (eds.) Human Rights in

Africa. Windhoek: Konrad Adenauer Stiftung \& MacMillan.

HRCP (2015). The State of Human Rights in Pakistan: Annual Report 2015. Retrieved from http://hrcp-web.org/hrcpweb/hrcp-annual-report-2015.

HREA (2010). Human Rights Education. Retrieved from HREA website http://www.hrea.org/.

HRW (2016). Annual Report 2016. Retrieved from https://www.hrw.org/world-report/2017/countrychapters/pakistan

Iqbal, N. (2005). Peace and Human Rights Education: Pakistan Experience. Human Rights

Education in Asian Schools, Volume VIII, Osaka, Asia-Pacific Human Rights Information Center.

Jahangir, Asma (2000). Human Rights in Pakistan: A System in the Making. Power, Samantha and

Allison, Graham, eds. Realizing Human Rights: Moving from Inspiration to Impact. New

York: St. Martin's Press, p. 167-194.

Learning and Educational Achievements in Punjab Schools (LEAPS) Report (2007), Retrieved from $\underline{\text { http://leapsproject.org/assets/publications/LEAPS_report.pdf. }}$

Little, A. (1992). Education and Development: Macro Relationships and Micro cultures. (Silver Jubilee Paper; 4). Sussex: Institute of Development Studies. 
Mihr, A., and Schmitz, H.P. (2007). Human Rights Education and Transnational Activism. Human Rights Quarterly 29 (4).

Nasab, A., and Meghdadi, M. (2012). Muslim clerics and leadership in human rights education in Muslim societies. Procedia-Social and Behavioral Sciences 2012.

Nisar, M.A. (2010). Education, Religion and the Creation of Subject: Different Educational Systems of Pakistan. Kent. Pakistaniaat: A Journal of Pakistan Studies

Vol 2, No 1 (2010): Spring Issue.

Nussbaum, M.C. (2010). Education and democratic citizenship: capabilities and quality education. Paper delivered at the second annual conference of the Human Development Capability Association, UNESCO, Paris.

Oxaal, Z. (1997). Education and Poverty: A Gender Analysis. Brighton, University of Sussex.

Pirzado, P. (2013). Human Rights Education in Pakistani Schools. Un-published thesis for Master of Human Rights and Democratisation, University of Sydney.

Population Council (1998). Pakistan Contraceptive Prevalence Survey 1994-95. Islamabad: Population Council, Ministry of Population Welfare.

Quddus, N. J. (1990). Problems of education in Pakistan. Karachi: Royal Book. Company.

Qureshi, Rashida \& Shamim, Fauzia (2009). Schools and schooling practises in Pakistan: lessons for policy and practise. New York, Oxford University Press, Oxford.

Qureshi, R. Pirzado, P. Nasim, S. (2007). Schooling in Rural Sindh..R. Qureshi and J. Rarieya (ed.), Gender and Education in Pakistan. Karachi, Oxford University Press.

Retallick, J., \& Farah, I. (Eds.). (2005). Transforming schools in Pakistan: Towards the learning community. Karachi: Oxford University Press (OUP).

Retallick, J. \& Datoo, A. (2005). Transforming Schools into Learning Communities. J. Retallick\& I. Farah (Eds.) Transforming Schools in Pakistan. Karachi, OUP.

Schofield, Victoria (2009). Can Democracy Work in Pakistan? Smith, Barney (Ed.), Asian Affairs, 40(2), pp. 243 - 251.

Schunk, D.H (1990). Self-concept and school achievement. C.Rogers and P. Kutnick (eds.) The social psychology of the primary school. London: Routledge.

Seker, Günes and Topsakal, Cem (2011). The level of ability to adopt and apply organizational democracy to primary schools according to perceptions of teachers and administrators. Academic journal article from Kuram ve Uygulamada Egitim Bilimleri, Vol. 11, No. 3. 
Shuttleworth, Mary B. (2008). Human rights education: A phenomenological explication.

Unpublished Dissertation retrieved from https://search-proquestcom.ezproxy.lib.uts.edu.au/docview/304837338/.

Siddiqui, S. (2010). Rethinking Education in Pakistan: Perceptions, Practises and Possibilities. Paramount Publishing Enterprise, Karachi.

Srinivasan,A. (2009). A Survey of Civil Society Peace Education Programs in South Asia. Tamil Nadu: Education for Peace.

Syed, J. (2008). A context-specific perspective of equal employment opportunity in Islamic societies. Asia Pacific Journal of Management, 25(1), 135-151.

The Office of the United Nations High Commissioner for Human Rights (2017). Ratification Status of Pakistan. Retrieved from the OHCHR website http://tbinternet.ohchr.org/_layouts/TreatyBodyExternal/Treaty.aspx?CountryID=131\&Lang $=\mathrm{EN}$.

Tibbitts, F. (2002). Understanding What We Do: Emerging Models for Human Rights Education. International Review of Education, 48 (3-4).

Tibbitts, F. (1996). On human dignity: A renewed call for human rights education. Social Education, 60(7), 428-431.

UNDP (2016). Human Development Report 2016. Retrieved from http://hdr.undp.org/sites/default/files/2016_human_development_report.pdf.

UNESCO (2017). Pakistan Education Statistics. Retrieved from http://uis.unesco.org/en/country/PK. UNESCO (2004). EFA Global Monitoring Report 2005. Education for All: The Quality Imperative. Paris, UNESCO.

UNESCO (1989). The Convention on the Rights of the Child. Paris, UNESCO.

UNESCO (1980). The Teaching of Human Rights. Paris, UNESCO.

UNICEF (2007). A Human Rights-Based Approach to Education. New York, UNICEF.

UDHR (2017). Universal Declaration of Human Rights (UDHR). Retrieved from http://udhr.org/UDHR/default.htm.

Verhellen, E. (1993). Children's rights and education. School Psychology International, 14, 3, p. 199-208.

Word Bank (2017). Pakistan's Military expenditure (\% of GDP). Retrieved from https://data.worldbank.org/indicator/MS.MIL.XPND.GD.ZS. 
Worldometers (2018). Pakistan's population. Retrieved from http://www.worldometers.info/worldpopulation/pakistan-population/

Yousafzai, Malala (2013). I am Malala: the girl who stood up for education and was shot by the Taliban. New York, NY: Little, Brown, \& Company. 